\title{
Peranan Pengendalian Internal dalam Menunjang Efektivitas Sistem Pemberian Kredit Usaha Kecil dan Menengah (Studi Kasus di Koperasi Pegawai BRI Cabang Kediri)
}

\author{
Munawaroh \\ STKIP PGRI Jombang \\ E-mail: munawarohw@yahoo.co.id
}

\begin{abstract}
The objective of this research is to find out the role of internal control to support the effectiveness of the loan systems for micro and middle enterprises given by BRI Kediri. The research design used in this study is a case study. The main finding of the research shows that the internal control has been effectively implemented. It can be seen that 93,75\% respondents agree with the effectiveness of internal control. There are 92,72\% respondents agree that the credit system is an effective system. Moreover, the role of internal control that supports the credit system is shown to be effective, where 93,65\% respondents agree with the effective role of internal control.
\end{abstract}

Keywords: effectiveness, internal control, micro credit system

\section{PENDAHULUAN}

Salah satu sektor potensial yang mendapat perhatian pemerintah dan perlu dikembangkan adalah sektor usaha kecil dan menengah. Namun demikian, sektor ini pada umumnya menghadapi masalah dalam berbagai aspek permodalan, seperti masalah pembiayaan usaha, masalah akumulasi modal, serta cara memanfaatkan fasilitas dalam rangka pelaksanaan usahanya.

Koperasi dalam hal ini berperan dalam membantu permasalahan yang dihadapi usaha kecil dan menengah melalui penyaluran kredit. Dengan peran serta koperasi terhadap usaha kecil dan menengah dalam pemberian kredit, maka usaha kecil dan menengah diharapkan dapat meningkatkan usahanya dengan kualitas yang lebih baik, sehingga usaha kecil dan menengah dapat membantu pertumbuhan ekonomi.

Salah satu unit usaha koperasi adalah memberikan kredit simpan pinjam. Pemberian kredit merupakan usaha koperasi yang paling pokok, sehingga koperasi perlu memberikan penilaian terhadap nasabah yang mengajukan kredit pinjaman serta merasa yakin bahwa nasabahnya mampu mengembalikan kredit yang diterimanya.

Masalah keamanan kredit yang diberikan merupakan masalah yang harus diperhatikan oleh koperasi, karena ada resiko yang timbul dalam sistem pemberian kredit. Permasalahan ini dapat dihindari dengan adanya pengendalian internal yang memadai dalam bidang perkreditan. Dengan kata lain, diperlukan suatu pengendalian yang dapat menunjang efektivitas pemberian kredit. Dengan terselenggaranya pengendalian internal yang memadai dalam pemberian kredit, berarti menunjukkan sikap kehatihatian dalam tubuh koperasi tersebut. Untuk mampu berperan sebagai badan usaha yang tangguh dan mandiri, koperasi melaui usaha pemberian kreditnya harus mampu meningkatkan efektivitas sistem pemberian kredit dan berusaha sebaik mungkin mengurangi resiko kegagalan kredit, terutama akibat lemahnya pengendalian internal.

Pengendalian internal yang baik diperoleh dari suatu struktur yang terkoordinasi yang berguna bagi pimpinan perusahaan untuk menyusun laporan keuangan yang lebih teliti, mencegah kecurangan dalam perusahaan, serta mengamankan harta perusahaan.

Alasan perusahaan menyusun pengendalian internal adalah dalam rangka membantu dalam mencapai tujuannya. Manajemen dalam menjalankan fungsinya membutuhkan sistem pengendalian yang dapat mengamankan harta perusahaan, memberikan keyakinan bahwa apa yang dilaporkan adalah benarbenar dapat dipercaya dan dapat mendorong adanya efisiensi usaha serta dapat terus menerus memantau bahwa kebijakan yang telah ditetapkan memang dijalankan sesuai dengan apa yang diharapkan.

Manajemen dalam koperasi melaksanakan kegiatan pengendalian internal bisa mempersiapkan sebaik mungkin mulai dari proses, personil, tujuan, serta apa saja yang dapat menjadi hambatan dalam pencapaian tujuan pengendalian internal. Pengendalian internal dirancang dengan memperhatikan kepentingan manajemen perusahaan dalam menye- 
lenggarakan operasi perusahaannya dan juga memperhatikan aspek biaya yang harus dikeluarkan, serta manfaat yang diharapkan. Arens \& Loebbecke (1999) yang menjadi tujuan pengendalian internal adalah reliability of financial reporting, efficiency and effectiveness of operation, serta compliance with applicable laws and regulation.

Pengendalian internal tidak dimaksudkan untuk menghilangkan semua kemungkinan terjadinya kesalahan dan penyelewengan sama sekali, tetapi pengendalian internal yang memadai akan dapat menekan atau memperkecil terjadinya kesalahan dan penyelewengan dalam batas yang layak dan kalaupun terjadi kesalahan atau penyelewengan dapat segera diketahui dan diatasi.

Komponen pengendalian internal merupakan proses untuk menghasilkan pengendalian yang memadai. Agar tujuan pengendalian tercapai, perusahaan harus mempertimbangkan komponen-komponen pengendalian internal.

Komponen-komponen pengendalian internal menurut Arens \& Loebbecke (1999:274) adalah sebagai berikut:

"Internal control include five cayegories of control that management's control objectives will be met. There are five components of internal control: (1) the control environment, (2) risk assessment, (3) control activities, (4) information and communication, (5) manitoring".

Pengendalian internal yang bagaimanapun baiknya, tidak dapat dianggap sepenuhnya efektif, karena selalu ada kemungkinan bahwa data yang dihasilkannya tidak akurat akibat adanya beberapa keterbatasan yang melekat pada sistem tersebut. Adapun keterbatasan bawaan yang melekat dalam setiap pengendalian internal menurut Mulyadi \& Puradireja (2002) adalah kesalahan dalam pertimbangan, gangguan, kolusi, dan pengabaian oleh manajemen.

Efektivitas sangat berkaitan dengan tujuan yang akan dicapai. Dalam usaha mencapai efektivitas sistem pemberian kredit, perlu diketahui tujuan pemberian kredit yang diharapkan. Untuk itu, bagian perkreditan perlu menetapkan kriteria tertentu untuk mencapai tujuan pemberian kredit. Dalam hal ini digunakan prinsup perkreditan yang lebih dikenal dengan prinsip 5C, yaitu character, capacity, capital, collateral, dan condition of economic. Apabila prinsip-prinsip tersebut terpenuhi, diharapkan tujuan pemberian kredit akan tercapai. Di samping itu, perlu dilaksanakannya prosedur pemberian kredit yang meliputi permohononan kredit, analisa kredit, keputusan kredit, perjanjian kredit serta pencairan kredit.
Selain terpenuhinya prinsip dan prosedur pemberian kredit, suatu sistem pemberian kredit dapat dikatakan efektif apabila kredit tersebut dapat kembali sesuai waktu yang ditetapkan dengan sejumlah bunga yang telah ditentukan. Prioritas pemberian kredit yang diberikan betul-betul tepat sasaran dan tepat guna, maka efektivitas sistem pemberian kredit akan tercapai. Setiap koperasi simpan pinjam harus memiliki struktur pengendalian internal yang memadai dalam perkreditan untuk mencegah penyalagunaan wewenang.

Adapun permasalahan-permasalahan yang diteliti pada studi ini adalah sebagai berikut:

1. Apakah pengendalian internal yang diterapkan koperasi sudah efektif?

2. Apakah sistem pemberian kredit usaha kecil dan menengah koperasi sudah efektif?

Sedangkan tujuan-tujuan dari penelitian adalah untuk:

1. Menjelaskan efektivitas pengendalian internal yang diterapkan Koperasi Pegawai BRI (KOPEBRI) Indonesia, Cabang Kediri.

2. Menjelaskan efektivitas sistem pemberian Kredit Usaha Kecil Menengah, Koperasi Pegawai BRI (KOPEBRI) Indonesia, Cabang Kediri

\section{METODE PENELITIAN}

\section{Rancangan Penelitian}

Metode yang digunakan dalam penelitian adalah metode deskriptif eksploratif. Jenis penelitian deskriptif yang digunakan adalah pendekatan studi kasus. Menurut (Nazir,2005), penelitian studi kasus adalah penelitian tentang kasus subyek penelitian yang berkenaan dengan suatu fase spesifik atau khas dari keseluruhan personalitas. Data yang diperoleh dari hasil penelitian, diproses kemudian dianalisis serta diinterpretasikan dengan teori yang ada. Penelitian ini dilaksanakan di Koperasi Pegawai Bank Rakyat Indonesia Cabang Kediri

Pada penelitian ini, aspek yang diteliti dari peranan pengendalian internal adalah komponen pengendalian internal dan tujuan pengendalian internal. Dilain pihak, efektivitas sistem pemberian kredit usaha kecil dan menengah diukur melalui tingkat kesesuaian pelaksanaan sistem pemberian kredit dengan indikator pelaksanaan sistem pemberian kredit yang efektif.

Definisi operasional dari variabel-variabel penelitian ini disajikan dalam Tabel 1. 
Tabel 1. Operasionalisasi Variabel

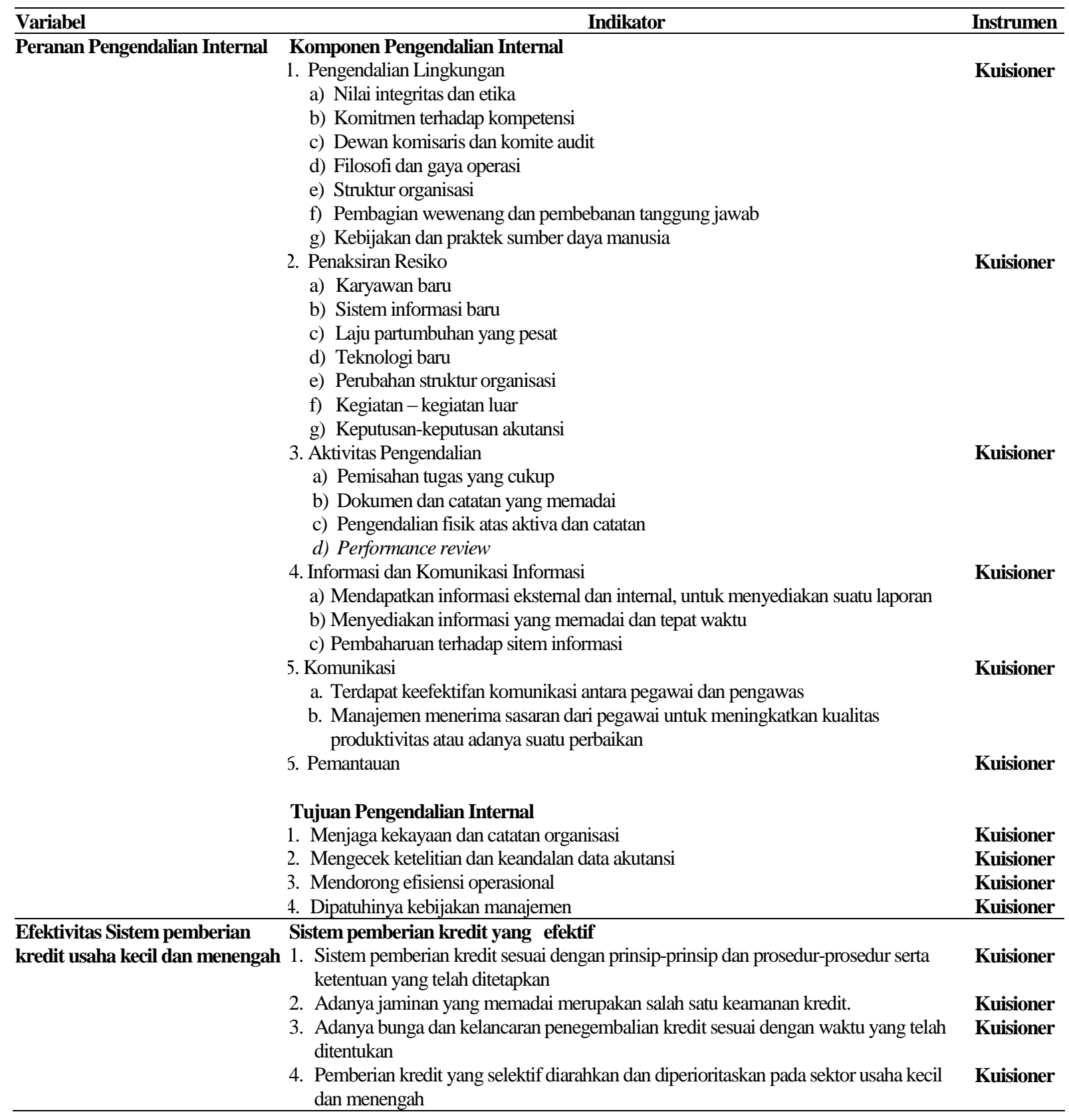

Dalam penelitian ini responden adalah karyawan Koperasi Pegawai Bank Rakyat Indonesia, Cabang Kediri sebanyak 5 orang yeng benar-benar mendalami permasalahan pemberian kredit. Hal ini sesuai dengan pendapat Arikunto (2006) yang mengatakan bahwa dalam menentukan jumlah sampel untuk sekedar memperkirakan dan subjeknya kurang dari 100, lebih baik diambil seluruhnya, sehingga penelitiannya merupakan penelitian populasi. Selanjutnya, jika jumlah subjeknya besar, dapat diambil antara 10$15 \%$ atau $20-25 \%$ atau lebih.

\section{Analisis Data}

Penelitian ini menggunakan analisis deskriptif kualitatif, yaitu data yang diperoleh dan dikumpulkan, kemudian dianalisis berdasarkan metode yang telah ditetapkan dan bertujuan untuk menguji sejauhmana peranan pengendalian internal dalam menunjang efektifvitas sistem pemberian kredit usaha kecil dan menengah.

Adapun langkah-langkah yang ditempuh dalam analisis ini adalah sebagai berikut: 
1. Menyebarkan daftar pertanyaan tertulis (kuesioner) kepada seluruh responden yang sebelumnya telah penulis tetapkan. Dalam hal ini ditetapkan lima responden yang penulis anggap mewakili terhadap permasalahan yang berhubungan dengan pelaksanaan pengendalian internal dan sistem pemberian kredit.

2. Pertanyaan terdiri dari dua bagian, yaitu bagian pertanyaan umum yang menyangkut identitas responden, dan pertanyaan khusus yang berhubungan dengan peranan pengendalian internal yang efektif dan efisien sistem pemberian kredit usaha kecil dan menengah.

3. Meminta dan mengumpulkan kembali seluruh daftar pertanyaan (kuesioner) yang telah diisi oleh responden.

4. Mengelompokkan jawaban berdasarkan masalah. Dimana dari seluruh jawaban responden atas pertanyaan khusus, dalam hal ini peranan pengendalian internal dihitung jumlah jawaban "ya", "Ragu-ragu", dan "Tidak". Demikian juga untuk pertanyaan khusus yang menyangkut efektifitas sistem pemberian kredit, dihitung jumlah "ya", "Ragu-Ragu", dan "Tidak".

5. Selanjutnya untuk setiap jawaban akan diberikan nilai jawaban "ya" nilanya 3, "ragu-ragu" nilainya 2, dan "Tidak" nilainya 1.

6. Menghitung jumlah jawaban "ya" dan banyaknya pertanyaan untuk setiap kelompok.

7. Memasukkan jumlah jawaban "ya" dan jumlah pertanyaan ke dalam rumus skor ideal:

$\frac{\text { Jumlah jawaban Ya }}{\text { Jumlah jawaban seluruh responden }} \times 100 \%$

8. Menghitung besarnya prosentase jawaban "ya", untuk setiap kelompok

Sesuai dengan topik yang penulis ambil, penulis melakukan interpretasi sebagai berikut: Pelaksanaan pengendalian internal yang efektif ditafsirkan menurut kategori seperti dibawah ini:

a. $0 \%-25 \%$, berarti pengendalian internal tidak efektif.

b. $26 \%-50 \%$, berarti pengendalian internal kurang efektif.

c. $51 \%-75 \%$, berarti pengendalian internal cukup efektif.

d. $76 \%-100 \%$, berarti pengendalian internal sangat efektif.

Untuk efektivitas sistem pemberian kredit usaha kecil dan menengah, interpretasi dari hasil yang diperoleh adalah: a. $0 \%-25 \%$ berarti sistem pemberian kredit usaha kecil dan menengah tidak efektif

b. 26\%-50\% berarti sistem pemberian kredit usaha kecil dan menengah kurang efektif

c. $51 \%-75 \%$ sistem pemberian kredit usaha kecil dan menengah cukup efektif

d. $76 \%-100 \%$ berarti sistem pemberian kredit usaha kecil dan menengah sangat efektif

a. Untuk mengetahui peranan pengendalian internal dalam menunjang efektivitas sistem pemberian kredit usaha kecil dan menengah

e. $0 \%-25 \%$ berarti sistem pengendalian internal tidak berperan atau sangat sedikit berperan dalam menunjang efektivitas sistem pemberian kredit usaha kecil dan menengah

f. $26 \%-50 \%$ berarti sistem pengendalian internal sedikit berperan dalam menunjang efektivitas sistem pemberian kredit usaha kecil dan menengah

g. $51 \%-75 \%$ berarti sistem pengendalian internal cukup berperan dalam menunjang efektivitas sistem pemberian kredit usaha kecil dan menengah

h. $76 \%-100 \%$ berarti sistem pengendalian internal sangat berperan dalam menunjang efektivitas sistem pemberian kredit usaha kecil dan menengah

Dengan demikian, sistem pengendalian internal dikatakan efektif jika:

a. Hasil jawaban peranan pengendalian internal memiliki angka angka $75 \%-100 \%$.

b. Hasil jawaban efektivitas sistem pemberian kredit berada pada kisaran 75\%-100\%.

\section{HASIL DAN PEMBAHASAN}

Untuk mengetahui peranan pengendalian internal dalam menunjang efektivitas sistem pemberian kredit usaha kecil dan menengah, penulis menggunakan penghitungan prosentase yang menunjukkan berapa besar peranan pengendalian internal dalam sistem pemberian kredit usaha kecil dan menengah.

Untuk variabel peranan pengendalian internal diperoleh jawaban seperti tersaji dalam Tabel 2.

Tabel 2. Gambaran Hasil Variabel Peranan Pengendalian Internal

\begin{tabular}{ccccc}
\hline \multirow{2}{*}{ Responden } & \multicolumn{3}{c}{ Jawaban } & Jumlah \\
\cline { 2 - 4 } & Ya & Ragu-ragu & Tidak & Pertanyaan \\
\cline { 2 - 4 } A & 37 & 2 & 1 & 40 \\
B & 39 & 0 & 1 & 40 \\
C & 33 & 3 & 4 & 40 \\
D & 34 & 2 & 4 & 40 \\
E & 32 & 3 & 5 & 40 \\
\hline Jumlah & $\mathbf{1 7 5}$ & $\mathbf{1 0}$ & $\mathbf{1 5}$ & $\mathbf{2 0 0}$ \\
\hline
\end{tabular}


Selanjutnya, seluruh hasil jawaban kuesioner dikalikan dengan kriteria nilai yang ditetapkan, yaitu "Ya" = 3, "Ragu-ragu" = 2 dan "Tidak" = 1 . Hasil jawaban akhir yang diperoleh sebagai berikut:

$$
\begin{array}{ll}
\text { Ya } & =175 \times 3=525 \\
\text { Ragu-ragu } & =10 \times 2=20 \\
\text { Tidak } & =15 \times 1=15 \\
\cline { 2 - 3 } &
\end{array}
$$

Prosentase jumlah jawaban "Ya" untuk pengendalian internal:

$$
\begin{aligned}
& \frac{\text { Jumlah jawaban Ya }}{\text { Jumlah jawaban seluruh responden }} \\
& \frac{525}{560} \times 100 \%=93.75 \%
\end{aligned}
$$

Dari perhitungan diatas, diperoleh hasil 93,75\%. Berdasarkan kriteria-kriteria penilaian hasil jawaban untuk pengendalian internal, hasil ini memberikan sinyal bahwa pengendalian internal yang diterapkan sudah sangat efektif. Sedangkan penilaian terhadap efektivitas sistem pemberian kredit, diperoleh hasil jawaban seperti tersaji dalam Tabel 3 .

Selanjutnya, seluruh hasil jawaban kuesioner dikalikan dengan kriteria nilai yang ditetapkan, yaitu "Ya" = 3, "Ragu-ragu" = 2 dan "Tidak" = 1 . Berdasarkan formulasi ini, diperoleh hasil jawaban sebagai berikut:

$$
\begin{array}{ll}
\text { Ya } & =17 \times 3=51 \\
\text { Ragu-ragu } & =1 \times 2=2 \\
\text { Tidak } & =2 \times 1=2 \\
\cline { 2 - 3 } &
\end{array}
$$

Tabel 3. Gambaran Hasil Variabel Efektivitas Sistem Pemberian Kredit Usaha Kecil dan Menengah

\begin{tabular}{ccccc}
\hline \multirow{2}{*}{ Responden } & \multicolumn{3}{c}{ Jawaban } & $\begin{array}{c}\text { Jumlah } \\
\text { Pertanyaan }\end{array}$ \\
\cline { 2 - 4 } & Ya & Ragu-ragu & Tidak & 4 \\
A & 4 & 0 & 0 & 4 \\
B & 3 & 1 & 0 & 4 \\
C & 3 & 0 & 1 & 4 \\
D & 4 & 0 & 0 & 4 \\
E & 3 & 0 & 1 & $\mathbf{2 0}$ \\
\hline Jumlah & $\mathbf{1 7}$ & $\mathbf{1}$ & $\mathbf{2}$ &
\end{tabular}

Prosentase jumlah jawaban "Ya" untuk efektivitas sistem pemberian kredit:

$$
\frac{\text { Jumlah jawaban Ya }}{\text { Jumlah jawaban seluruh responden }} \times 100 \%=
$$$$
\frac{51}{55} \times 100 \%=92.72 \%
$$

Dari perhitungan diatas, diperoleh hasil 92,72\%. Hasil ini memberikan informasi jika pemberian kredit usaha kecil dan menengah sudah sangat efektif.

Untuk mengetahui peranan pengendalian internal dalam menunjang pemberian kredit usaha kecil dan menengah, penulis menjumlahkan seluruh jawaban kuesioner dan kemudian mengalikannya dengan kriteria nilai yang telah ditetapkan. Untuk lebih jelas dapat dilihat pada Tabel 4.

Tabel 4. Gambaran Peranan Pengendalian Internal dalam Menunjang Efektivitas Sistem Pemberian Kredit Usaha Kecil dan Menengah

\begin{tabular}{ccccc}
\hline \multirow{2}{*}{ Responden } & \multicolumn{3}{c}{ Jawaban } & $\begin{array}{c}\text { Jumlah } \\
\text { Pertanyaan }\end{array}$ \\
\cline { 2 - 4 } & Ya & Ragu-ragu & Tidak & 44 \\
A & 41 & 2 & 1 & 44 \\
B & 42 & 1 & 1 & 44 \\
C & 36 & 3 & 5 & 44 \\
D & 38 & 2 & 4 & 44 \\
E & 35 & 3 & 6 & $\mathbf{2 2 0}$ \\
\hline Jumlah & $\mathbf{1 9 2}$ & $\mathbf{1 1}$ & $\mathbf{1 7}$ &
\end{tabular}

Selanjutnya seluruh hasil jawaban kuesioner dikalikan dengan kriteria nilai yang ditetapkan, sehingga diperoleh hasil jawaban sebagai berikut:

$\mathrm{Ya}=192 \times 3=576$

Ragu-ragu $=11 \times 2=22$

Tidak $=17 \times 1=17$

\section{5}

Prosentase jumlah jawaban "Ya" untuk peranan pengendalian internal:

$$
\begin{aligned}
& \frac{\text { Jumlah jawaban Ya }}{\text { Jumlah jawaban seluruh responden }} \times 100 \%= \\
& \frac{576}{615} \times 100 \%=93.65 \%
\end{aligned}
$$

Dari perhitungan diatas, diperoleh hasil 93,65\%. Hal ini memberikan suatu indikasi bahwa pengendalian internal sangat berperan dalam menunjang efektivitas sistem pemberian kredit usaha kecil dan menengah.

\section{Pembahasan}

Pengendalian internal dan sistem pemberian kredit pada Koperasi Pegawai Bank Rakyat Indonesia (KOPEBRI), Kediri, telah dilaksanakan secara efektif. Sistem pengendalian internal pada koperasi ini juga berperan dalam menunjang efektivitas sistem pemberian kredit usaha kecil menengah. Dengan demikian, untuk mencapai efektivitas sistem pemberian kredit perlu diketahui tujuan pemberian kredit yang diharapkan. Untuk itu, bagian perkreditan perlu menetapkan kriteria-kriteria tertentu guna mencapai tujuan pemberian kredit. Kriteria-kriteria seperti 5C, yaitu character, capacity, capital, coolateral dan condition of economic tetap relevan. Apabila prinsip tersebut terpenuhi, diharapkan tujuan pemberian kredit akan tercapai. Di samping itu, perlu dilaksanakannya prosedur pemberian kredit yang meliputi permohononan kredit, analisa kredit, keputusan kredit, perjanjian kredit serta pencairan kredit. 
Selain terpenuhinya prinsip dan prosedur pemberian kredit, suatu sistem pemberian kredit dapat dikatakan efektif apabila kredit tersebut dapat kembali sesuai waktu yang ditetapkan dengan sejumlah bunga yang telah ditentukan. Prioritas pemberian kredit yang diberikan betul-betul tepat sasaran dan tepat guna.

Mengingat pemberian kredit merupakan suatu usaha koperasi yang paling pokok, maka koperasi perlu memberikan penilaian terhadap nasabah yang mengajukan kredit pinjaman serta merasa yakin bahwa nasabahnya tersebut mampu untuk mengembalikan kredit yang telah diterimanya. Masalah keamanan atas kredit yang diberikan merupakan masalah yang harus diperhatikan oleh koperasi, karena adanya resiko yang timbul dalam sistem pemberian kredit. Permasalahan ini bisa dihindari dengan adanya suatu pengendalian internal yang memadai dalam bidang perkreditan. Dengan kata lain, diperlukan suatu pengendalian internal yang dapat menunjang efektivitas sistem pemberian kredit

Setiap koperasi simpan pinjam harus memiliki struktur pengendalian internal yang memadai dalam perkreditan untuk mencegah penyalagunaan wewenang. Beberapa pokok utama dalam pengendalian internal kredit menurut Tawaf (1999) adalah:

1. Harus ada sistem pengendalian internal yang baik, dalam arti pemisahan fungsi antara pejabat yang menyetujui kredit, melakukan pembayaran kepada debitur, penagihan, analisis, administrasi kredit, dan taksiran agunan.

2. Harus ada kebijakan perkreditan tertulis yang telah disetujui direksi.

3. Harus ada aparat kompeten yang akan memproses kredit. Artinya, para pengelola kredit di koperasi harus mempunyai pengetahuan yang cukup serta keterampilan yang memadai dalam menangani permasalahan kreditnya.

4. Harus ada fungsi review terhadap kredit yang telah diberikan dan manajemen harus selalu memantau pelaksanaan review tersebut. Dalam hubungan ini, pelaksanaan review serta pemantauan tindak lanjut atas masalah yang ada harus dilakukan secara terus menerus dan dibangun dengan sistem yang terorganisir, sehingga mampu melakukan deteksi dini atas permasalahan yang ada berikut penanganan tindak lanjutnya.

Dengan terselenggaranya pengendalian internal yang memadai dalam bidang perkreditan, berarti menunjukkan sikap kehati-hatian dalam tubuh koperasi tersebut. Untuk mampu berperan sebagai badan usaha yang tangguh dan mandiri, koperasi melalui usaha pemberian kreditnya harus mampu meningkatkan efektivitas sistem pemberian kredit dan berusaha sebaik mungkin mengurangi resiko kegagalan kredit. Jika diteliti lebih dalam, kegagalan kredit terutama disebabkan oleh lemahnya pengendalian internal.

\section{KESIMPULAN DAN SARAN}

\section{Kesimpulan}

Berdasarkan penelitian yang penulis lakukan pada Koperasi Pegawai Bank Rakyat Indonesia (KOPEBRI), Kediri, penulis menyimpulkan bahwa pengendalian internal yang diterapkan pada Koperasi Pegawai Bank Rakyat Indonesia (KOPEBRI), Kediri, dan sistem pengendalian internal tersebut telah efektif. Hal ini didukung oleh hasil jawaban kuesioner yang berhubungan dengan efektivitas pengendalian internal sebesar $93,75 \%$.

Sistem pemberian kredit yang diterapkan di Koperasi Pegawai Bank Rakyat Indonesia (KOPEBRI), Kediri, telah efektif. Hal ini didukung oleh hasil jawaban kuesioner yang berhubungan dengan efektivitas pemberian kredit sebesar 92,72\%.

Peranan pengendalian internal dalam menunjang efektivitas pemberian kredit tidak dapat diabaikan. Hal ini di dukung oleh hasil jawaban kuesioner yang berhubungan dengan peranan pengendalian internal dalam menunjang efektivitas pemberian kredit sebesar 93,65\%.

\section{Saran}

Adapun saran-saran yang sekiranya dapat menjadi pertimbangan antara lain: pemeriksaaan dan pemantauan kredit seyogyanya dilakukan sesering mungkin, sehingga jika terjadi masalah dapat diketahui sejak dini. Selain itu, koperasi hendaknya membuat laporan tentang perkembangan usaha nasabah, untuk mengetahui apakah kredit yang diberikan menjadikan usaha nasabah menjadi lebih berkembang dan untuk mengetahui secara pasti kesesuaian antara penggunaan dana kredit oleh nasabah dengan tujuan yang tercantum dalam syarat permohononan kredit.

\section{DAFTAR PUSTAKA}

Arens, A. Alvin \& James K. Loebbecke. 1999. Auditing: Suatu Pendekatan Terpadu, Edisi Keempat, Jakarta: Penerbit Erlangga.

Arikunto, S. 2006. Prosedur Penelitian: Suatu Pendekatan Praktik. Edisi Revisi VI. Jakarta: Bina Aksara. 
Mulyadi \&Kanaka Puradireja. 2002. Auditing, Edisi Kelima, Jakarta: Penerbit Salemba Empat.

Nazir, M. 2005. Metode Penelitian, Jakarta: Ghalia Indah.

Tawaf, Tjukria P. 1999. Audit Intern Bank, Jakarta: Salemba Empat. 